\title{
PH
}

bienes, paisajes e itinerarios

\section{Información de bienes culturales. Sierra Morena cordobesa}

La Guía Digital del Patrimonio Cultural de Andalucía, desarrollada por el IAPH (http://www.iaph.es/web/canales/ conoce-el-patrimonio/guia-digital/), nos ofrece, de forma integrada, toda la información patrimonial de los municipios andaluces.

La demarcación de Sierra Morena de Córdoba comprende los municipios de Adamuz, Espiel, Obejo, Villanueva del Rey, Villaviciosa de Córdoba, Fuente Obejuna, Hornachuelos, Peñarroya-Pueblonuevo, Los Blazquez y Belmez. El conjunto de estos municipios ocupa la zona central de la provincia, entre el valle de los Pedroches y la vega del Guadalquivir.

Centro de Documentación y Estudios del IAPH

URL de la contribución <www.iaph.es/revistaph/index.php/revistaph/article/view/3843>

\section{Patrimonio inmueble}

En la Guía Digital del Patrimonio Cultural se encuentra la información referida a un total de 469 inmuebles de esta demarcación, de los cuales el $49 \%$ corresponde al patrimonio arquitectónico; el $30 \%$, al patrimonio arqueológico; y el $21 \%$, al patrimonio etnológico. También se puede consultar información referida a estos inmuebles en la base de datos del Patrimonio Inmueble de Andalucía (http://www.iaph.es/patrimonio -inmueble-andalucia/).

El poblamiento en la demarcación evoluciona desde el tipo de asentamiento en cuevas en el paleolítico y postpaleolítico con el ejemplo del abrigo Carmelo en Peñarroya-Pueblonuevo, hasta la implantación de poblados vinculados a la explotación agraria y minera a partir de la Edad del Cobre, en la que se documentan poblados como Sierra Palacios en Belmez o La Caraveruela en Fuente Obejuna. Estos poblados se asocian con manifestaciones megalíticas contando con ejemplos como el dolmen de la Camorrilla (Obejo), el dolmen de Casas de Don Pedro (Bélmez), el dolmen de la Vega del Toro (Belmez), el dolmen de Peña Blanca (Espiel) o el dolmen de Huerta del Caño (Espiel).

Durante la época romana la urbanización tuvo como factor clave el interés minero del Guadiato, destacando de esta época la mina de la Loba, en Fuente Obejuna. También de época romana destaca el área arqueológica cerro de la Coja, en Obejo, donde se encuentran documentados asentamientos y pozos mineros. Se localizan también en la zona gran número de villae y alfares relacionados con la explotación agraria.

En el periodo islámico se hace muy evidente la fortificación del territorio debido a su compartimentación en taifas y a los levantamientos interiores contra el califa cordobés. Sobresalen el castillo de Ubal en Obejo, castillo Vacar y el de Sierra del
Castillo en Espiel, castillo de Belmez y castillo de Viandar en El Hoyo, en Belmez o el recinto amurallado de Hornachuelos.

De la Edad Moderna se contabilizan algunas construcciones religiosas en el área estudiada, como la iglesia mudéjar de Santa M. ${ }^{a}$ de las Flores en Hornachuelos y la iglesia de Nuestra Señora del Rosario en Peñarroya-Pueblonuevo, ambas inscritas como BIC en el Catálogo General del Patrimonio Histórico Andaluz (CGPHA). Se encuentran también registradas varias ermitas de estos municipios que forman parte del Inventario de las Ermitas de la Provincia de Córdoba.

En cuanto al patrimonio industrial, ligado en esta zona fundamentalmente a la actividad minera, hemos de destacar el sitio histórico de Cerro Muriano y el cerco industrial de Peñarroya-Pueblonuevo.

El interés patrimonial del sitio histórico de la zona minera de Cerro Muriano, en 
los términos municipales de Córdoba y Obejo (Córdoba) está asociado a la constatación de valores históricos, geológicos, paisajísticos, arqueológicos, tecnológicos y etnológicos, tal como evidencian y expresan las numerosas y diversas tipologías edificatorias que hoy persisten en Cerro Muriano, vestigios de una dilatada actividad minera desarrollada desde el calcolítico hasta los años 60 del siglo $X X$.

La zona minera comprende veintiuna áreas patrimoniales, entre las que se encuentran yacimientos arqueológicos, pozos, minas, estructuras de fundiciones y de tratamiento del cobre, así como construcciones relacionadas con el transporte del mineral y restos de estructuras de las casas de mineros e incluso utensilios muebles, bienes todos ellos que testimonian el desarrollo de una de las industrias extractivas más antiguas y relevantes de Andalucía.

La comarca cordobesa del Alto Guadiato constituye una de las zonas de más antiguo laboreo del carbón desde finales del siglo XVIII. El conjunto minero que ha llegado hasta la actualidad arranca en el siglo XIX e incluye múltiples minas e inmuebles industriales en los municipios de Peñarroya-Pueblonuevo, Belmez, Espiel o Fuente Obejuna. Destacan elementos como los castilletes de bocamina en hierro o mampostería como los de pozo Aurora, de Cervantes, o el Castillete del pozo Montera. Una vez abandonadas hoy casi en su totalidad la extracción y la siderurgia, el alto Guadiato ofrece un variado patrimonio industrial como testigo de una intensa actividad minera y metalúrgica en cortas, cabrias y pozos, instalaciones industriales y ferroviarias, e incluso barrios y poblados mineros.
Por su parte, de la edad contemporánea se encuentran documentados 11 inmuebles del siglo $X X$ pertenecientes al Registro Andaluz de Arquitectura Contemporánea en la zona estudiada.

Las principales fuentes de información sobre el patrimonio inmueble de Sierra Morena de Córdoba son el Catálogo de Yacimientos Arqueológicos con Pinturas Rupestres, el Inventario de Yacimientos Arqueológicos de Andalucía, el Inventario de Arquitectura Popular, el Inventario de Cementerios de Andalucía, el Inventario de Cortijos, Haciendas y Lagares, el Registro Andaluz de Arquitectura Contemporánea, el Inventario de Fuentes de la Provincia de Córdoba, el Inventario de Ermitas de la Provincia de Córdoba y el Boletín Oficial de la Junta de Andalucía para los bienes protegidos.

\section{Patrimonio mueble}

En la Guía Digital del Patrimonio Cultural también puede consultarse la información referida a 59 objetos muebles de carácter artístico de Sierra Morena de Córdoba, distribuidos en seis munici-

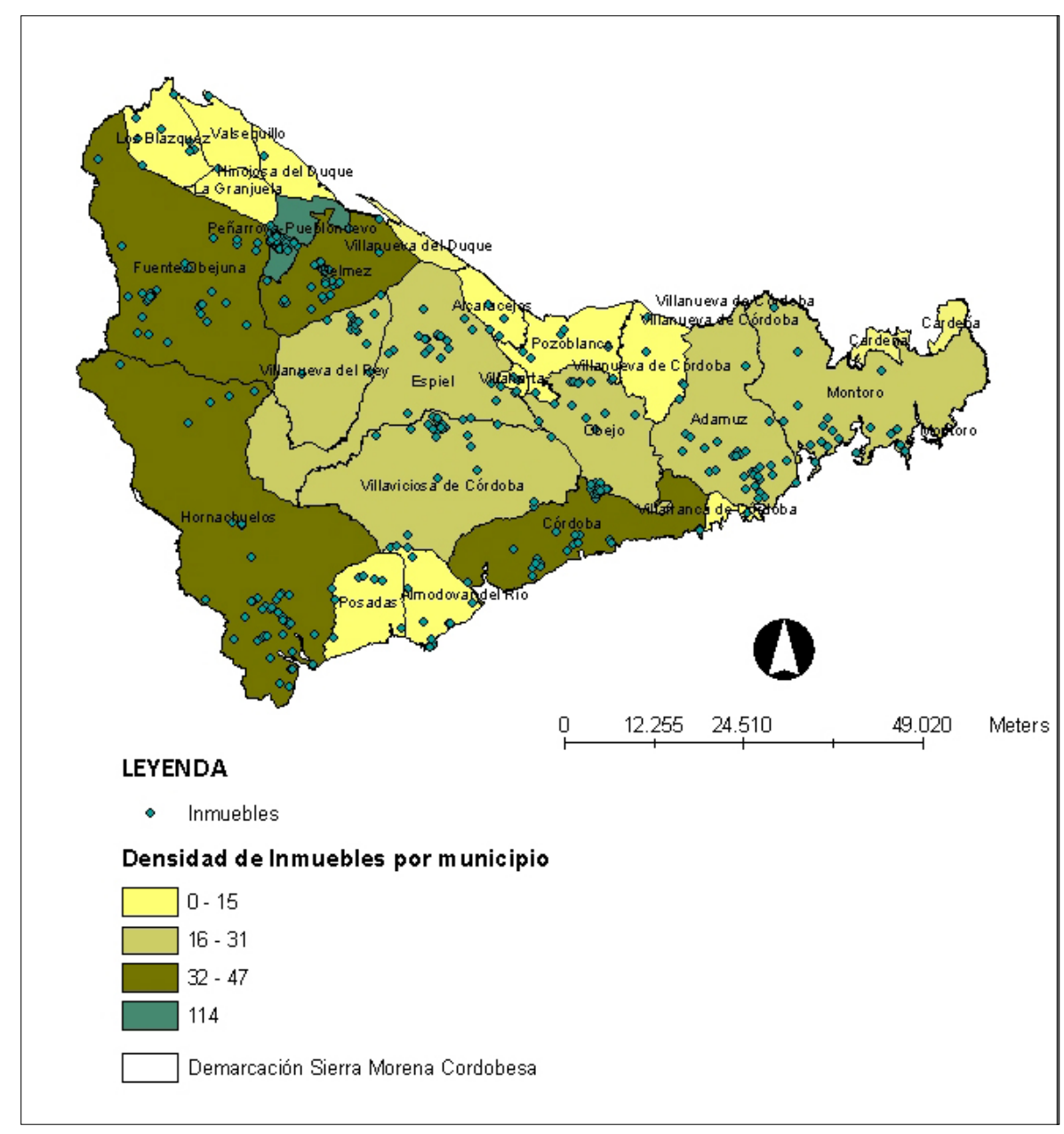

Distribución del patrimonio inmueble de la demarcación Sierra Morena de Córdoba 
pios y pertenecientes la mayor parte de ellos al Inventario de Bienes Muebles en Ermitas de Córdoba, algunos al Inventario de Bienes Muebles de la Iglesia Católica y otros al Registro de Patrimonio Cultural de la Universidad de Córdoba. Se puede consultar la base de datos del patrimonio Mueble de Andalucía en: http://www.iaph.es/ patrimonio-mueble-andalucia/

\section{Bibliografía}

En cuanto a la bibliografía se contabilizan en la Guía Digital un total de 249 referencias bibliográficas sobre Sierra Morena de Córdoba. El municipio que posee mayor cantidad de referencias es Fuente Obejuna (62), seguido de Espiel (39), Belmez y Adamuz (29) y PeñarroyaPueblonuevo (28).

\section{Cartografía}

Se encuentran georreferenciados en la zona 253 inmuebles, 143 puntuales y 110 poligonales, algunos de los cuales pueden consultarse a través del Localizador Cartográfico del Patrimonio Cultural: http://www.iaph.es/localizadorcartografico-patrimonio-cultural-andalucia/

\section{Patrimonio Inmaterial}

En el Atlas del Patrimonio Inmaterial de Andalucía se encuentran actualmente documentados 15 actividades de interés etnológico de Sierra Morena de Córdoba que, según los ámbitos temáticos, se distribuyen de la siguiente manera:

$>$ Rituales festivos: 6 registros

$>$ Oficios y saberes: 5 registros

> Alimentación y sistemas culinarios: 4 registros

Información disponible en: http://www. iaph.es/patrimonio-inmaterial-andalucia/ frmSimple.do

\section{Repositorio de Activos Digitales}

En nuestro Repositorio de Activos Digitales (http://repositorio.iaph.es/) se contabiliza un total de 827 imágenes de Sierra Morena cordobesa:

> imágenes de inmuebles: 741

> imágenes de patrimonio inmaterial: 86

\section{Rutas Culturales}

En la Guía hay dos rutas culturales que se encuadran en la zona que estudiamos:

Una de ellas es la ruta "Córdoba, memoria e industria. La Cuenca Minera del Carbón del Alto Guadiato": en las estribaciones meridionales de Sierra Morena la comarca cordobesa del alto Guadiato configura un territorio determinado por el desarrollo de la minería, actividad que ha generado unas características peculiares, que han dotado a estas tierras de una singularidad específica. Los municipios de Belmez y Peñarroya-Pueblonuevo sintetizan la relación y trascendencia que la minería ha tenido en estas tierras ya que tanto su esplendor como su declive han corrido paralelos a esta actividad (http:// www.iaph.es/web/canales/conoce-elpatrimonio/rutas-culturales/contenido/ Rutas_propias/01_02_Cuenca_minera_ alto_guadiato)

La otra ruta es "La minería en Sierra Morena: Cerro Muriano (Córdoba)": el patrimonio cultural y natural de Cerro Muriano destaca por su importancia en estrecha relación con la actividad minera. Además, la historia y las formas de vida de este lugar se cuentan a través de la huella plasmada por diferentes civilizaciones que, para la explotación de las minas de cobre, han pasado por este enclave.
Con esta ruta se recorren diferentes puntos de la zona de Cerro Muriano, a caballo entre los términos municipales de Obejo y Córdoba, donde se puede hacer un repaso de los diferentes pueblos que han pasado por este territorio a través de la labor minera y, lo que resulta más enriquecedor, comprobar cómo esta actividad ha impregnado a los habitantes de tal modo que, aunque ya extinguida, sigue siendo fundamental para comprender la esencia de Cerro Muriano (http://www.iaph.es/ web/canales/conoce-el-patrimonio/rutasculturales/contenido/Rutas_propias/ ruta_la_mineria_en_sierra_morena_ cerro_muriano_cordoba.html) 